\title{
Notes
}

\section{Fact Construction and Judgment in Constitutional Adjudication}

\author{
Emmet T. Flood
}

\section{INTRODUCTION}

This Note argues that judicial fact construction is an ignored and yet central issue in any theory of adjudication. Its thesis is this: there is a moment in judicial fact construction, overlooked in our customary thinking about adjudication, in which the facts are brought together to constitute a single unified whole. Attention to this moment of judgment, a judgment I call-borrowing from the philosopher of history Louis Mink-synoptic judgment, should help fill in a gap in theorizing about adjudication and enrich the understanding of the phenomenology of the judging process. No theory of adjudication can aspire to completeness without an account of how the "actual" facts engendering the case or controversy become the "fact-pattern" through which the law is applied.

Although it is by now a jurisprudential commonplace (albeit a contested commonplace) to assert that adjudication is interpretation, ${ }^{1}$ little attention has been paid to the specifically interpretive activity of fact construction. ${ }^{2}$ The struggle among interpretive theories has largely been played out in the arenas of constitutional and statutory interpretation. The principal purpose of this Note

1. For the idea that adjudication is interpretation, see R. DWORKIN, LAW's EMPIRE 87-92 \& passim (1986). But see Cornell, Adjudication Is Not Interpretation: Some Reservations About the Law as Literature Movement, 54 TENN. L. REV. 203 (1986).

2. An outstanding exception to this is Kelman, Interpretive Construction in the Substantive Criminal Law, 33 STAN. L. REV. 591 (1981); see infra text accompanying notes 63-65. 
is to fix attention on the process of fact construction, the synthetic act of synoptic judgment. Accordingly, this Note is descriptive rather than advocatory. Although it may have incidental implications for the longstanding debates concerning the proper approach to the Constitution, ${ }^{3}$ the Note's emphasis on fact construction is intended to be a contribution to our understanding of the actual process of adjudication. The Note offers not a theory of adjudication, but an account of a necessary component of that process; given serious attention, the account may provoke a rethinking of terms in some of the larger debates about legal interpretation.

First, however, it is necessary to bring into focus that portion of the adjudicative process that remains largely overlooked in theoretical accounts of judging. The perception of fact construction as a process worthy of attention and deserving of theorization itself depends largely upon the terms of the inquiry brought to bear on the problem of adjudication. Whether one regards the process of fact construction as deserving of theorization at all depends on whether it is noticed as a problem. As a general matter, it is fair to say that existing theories of constitutional adjudication do not offer competing (or even incommensurable) accounts of fact construction. The fact construction process is not regarded as an object worthy of theoretical scrutiny at all, and thus remains largely invisible to theories of adjudication.

I want to highlight this oversight by discussing Margaret Jane Radin's recent restatement of the idea of "The Rule of Law," a concept that is the cornerstone of much liberal thinking about adjudication. ${ }^{4}$ She writes that "[ [] he

3. It may also have implications for more localized jurisprudential debates such as the one concerning law as an autonomous discipline. See Fried, The Artificial Reason of the Law or: What Lawyers Know, 60 TEX. L. REV. 35 (1981); Posner, Conventionalism: The Key to Law as an Autonomous Discipline?, 33 U. TORONTO L.J. 333 (1988) [hereinafter, Posner, Conventionalism]; Posner, The Decline of Law as an Autonomous Discipline, 100 HARV. L. REV. 761 (1987); see also infra text accompanying notes 75-79.

4. Radin, Reconsidering the Rule of Law, 69 B.U.L. REV. 781 (1989).

Discussion of the idea of the rule of law is a staple of Anglo-American jurisprudence. J.M. Balkin captures the idea of the rule of law in terms of its demand that law be "predictable, nonretroactive, and equally applicable to all citizens." Balkin, The Rule of Law as a Source of Constitutional Change, 6 CONST. COMMENTARY 21, 21 (1989). Its values are "maximized by constrained interpretation of the Constitution." Moore, The Constitution as Hard Law, 6 CONST. COMMENTARY 51, 66 (1989). Traditionally, the idea of "the rule of law" has been associated with the idea of decision according to a rule. See Schauer, Rules, the Rule of Law, and the Constitution, 6 CONST. COMMENTARY 69, 69 (1989). The idea of adjudication as the application of rules of deductive reasoning to fact situations was, at least in its Langdellian version, discredited by Holmes and his Legal Realist epigones. But the desire to constrain judges is a persistent one, especially in light of the widely shared goals associated with the idea of the rule of law, and should not be dismissed too lightly. The last 10 years have witnessed a resurgence of interest in the idea of constitutional interpretive adjudication and a corresponding debate about the hows and whys of judicial guidance. The debate is often frankly motivated by "rule of law" values and a concomitant desire for interpretive consistency and rationality.

This debate has typically been dyadic in form, variously opposing interpretivism to noninterpretivism, originalism to nonoriginalism, and more recently "hard law" to "soft law." Throughout these debates, there recurs the disposition to identify constitutional adjudication as, at bottom, the application of a constraining methodology involving rules, or something approximating them.

Frederick Schauer has argued that the central question of constitutional adjudication is just this question of rules. See Schauer, supra. Shall one (two, or all somehow) of the possible rule-based adjudicative approaches be implemented as a calculus of constitutional adjudication, or should one (two, or all) of these 
Rule of Law, as it comes down to us in the liberal tradition, is committed to the model of rules, and this means, under the traditional conception of rules, that it is committed to traditional formalism." Traditional formalism understands the essence of adjudication to consist of the application of a rule to a particular. Rules apply to particulars in such a way that the particular can be fitted within the rule. One way of expressing this "is to think that somehow the applications to particulars are already present in the rule itself." 6

Traditional formalism's account of adjudication is relevant here not for the long-discredited (but nevertheless incessantly condemned) deductive-mechanical structure it adumbrates, but because in setting out the components of the adjudicative process (a judge, a rule, a "particular" to which the rule is applied), it allows us to isolate the central foci of interpretive inquiry in a way that makes them available for critical inspection. In the rule-of-law model the judge's role in adjudication is negligible, and beyond interpretive inquiry. ${ }^{7}$ For traditional formalism, the question of rules and their interpretation comes into the foreground ${ }^{8}$ and the situations to which the rules are applied remain opaque. By their very name, "particulars," the facts to which the rules apply,

be utilized only to supplement the freer activities of judges, assisting the judge in arriving at what he thinks the best outcome?

In spite of other differences, the approaches paired above generally share a common assumption-that it is possible to appeal to a consistent interpretive standard to secure the interpreted meaning of the Constitution: text, intention, structure, supervening values, contemporary consensus, the personal philosophy of the judge, or some ordered combination of these. Furthermore, in adhering to a secure interpretive standard, interpretive rationality in the form of rough predictability will emerge.

5. Radin, supra note 4 , at 796.

6. Id. at 795 .

7. Legal Realism has of course made us familiar with the relevance of the idiosyncracies of the decisionmaker. Though Legal Realism is by now old news, the revelations of Legal Realism still cannot be reconciled with the rule-of-law conception of the judicial factfinder that dominates so much of our thinking about interpretation. That model posits a contemporary, but historically unconditioned interpreter who then chooses from among contexts in which to situate the constitutional text.

While any number of contemporary approaches to interpretation part company with this structural model, the most helpful, I believe, is that of H.-G. Gadamer. See Linge, Editor's Introduction to H.-G. GADAMER, PHILOSOPHICAL HERMENEUTICS at xlvii (D. Linge ed. \& trans. 1976) [hereinafter Linge] ("All deliberate interpretation takes place on the basis of [human being's] historicity, that is on the basis of a prereflective understanding of being from within a concrete situation that has intrinsic relation to the interpreter's past and future."). Gadamer posits an historically conditioned interpreter capable of engaging a text such as the Constitution because the text itself and the history of its effects are constitutive elements of the very tradition in and through which the interpreting subject comes to understand. In understanding, we always understand texts as contextualized in historically conditioned ways. We do not first consult the text and then elect to place it in a context; rather we encounter it in a dialogue in which its original context, the history of its interpretations, and our present contexts merge. The understanding interpreter is herself historical; because she stands within, rather than above the stream of history, she is not free to pick and choose among contexts or methods that privilege an isolated past or an immediate present. See also infra notes 51-54 and accompanying text.

8. So, for instance, in the context of constitutional adjudication, a number of options present themselves as candidates for supplying the rules of adjudication. Among these are some very familiar ones: the constitutional text itself as the source of rules, the original intention of the Framers and/or ratifiers as the source of rules, and stare decisis as the source of rules for constitutional decisionmaking. 
are inarticulate, resistant to understanding, for in the language of modern ontology, "particulars" are ultimate simples, building blocks, atoms."

A crude model emerges. Constitutional interpretation is typically conceived as a process in which a judge (or judges) applies the Constitution (and/or a line of precedental cases) to a new and challenging issue which is grounded in some factual situation. The issue or fact situation is "held up" before the literal text of the Constitution (and/or before mediating structures in the form of evidence of original intent or intervening texts of doctrinal elaboration), and the issue is decided through the application of the Constitution. Judges may consult the words of the constitutional text, the intent of the Framers, precedents, values (enduring or contemporary), or some combination of all of these in order to arrive at a solution. The model has three parts: the judge, the case or controversy before the court, and the legal standard of review (that is, the text of the Constitution and as many of the other interpretive guides as are used in a given case). The process consists of the application by the judge of the interpreted text(s) to the facts in issue.

But if adjudication is the application of law $^{10}$ to concrete real-world situations, ${ }^{11}$ then the objects to which they are applied simply cannot be "particulars" in any way approximating the rule-of-law sense. ${ }^{12}$ Situations are compos-

9. "[W] take [it] to be a fact of human experience ... that a particular really is an instance of its universal." Universals, in 7-8 ENCYCLOPEDIA OF PHLOSOPHY 197 (P. Edwards ed. 1967) (discussing Aristotle). A philosophical universal can be thought of in terms of a rule: Any particular object satisfying the rule becomes an instance of it. See generally UNIVERSALS AND PARTICULARS (M. Loux ed. 1976) (discussing perennial philosophical problem of universals and particulars).

10. The perspective offered in this Note challenges not only the reigning characterization of the components of the adjudicative process, but also its combinational logic. What does it mean to "apply" an interpretive standard such as a constitutional provision or a statute? Though we think of grasping the thing to be applied and then, in the next moment, actually applying it, this image misses the way in which the judge has already begun to interpret, to understand the text, before she consciously begins to apply it to any particular situation.

11. The companion idea to Gadamer's notion of textual interpretation is his conviction that situations, present realities, are also always interpreted. The facts of a legal controversy do not stand naked, ready to be subsumed under a distinct and separate binding instrument called the law. Rather, "[C]ircumstances must be understood within the law ...." J. WEINSHEMER, GADAMER's HERMENEUTICs 191 (1985); see also infra notes 51-53 and accompanying text.

12. Of course we understand this tacitly, but we seldom make the interpretation of factual reality an object of reflection. A theoretical corollary of the rule-of-law model is that for adjudication there is a relatively clear-cut difference between facts and texts. Texts like the Constitution and statutes are open to interpretation; understanding reality, whatever else it may require of us, does not involve interpretation. The perspective relied upon in this Note argues that there can be no sharp differentiation between the interpretation of texts and facts. While a number of philosophical perspectives on understanding are available to underwrite that view, this Note relies on the phenomenological hermeneutics of Hans-Georg Gadamer. See supra note 7.

Three interesting discussions of Gadamer's relevance to contemporary debates about legal interpretation are Eskridge, Gadamer/Statutory Interpretation, 90 CoLUM. L. REV. 609 (1990); Hoy, Interpreting the Law: Hermeneutical and Poststructuralist Perspectives, 58 S. CAL. L. REV. 135 (1985); and Phelps \& Pitts, Questioning the Text: The Significance of Phenomenological Hermeneutics for Legal Interpretation, 29 ST. LOUS U.L.J. 353 (1985). For Gadamer, understanding a text such as the Constitution can never be either a matter of just consulting the semantic context of the Constitution's origin or of the world of the contemporary interpreter. Interpreting the Constitution involves a joining or fusing of the original context of the text and the contextual world of the interpreter. Neither context is dispensable and textual meaning can never 
ite, multifaceted, and, in adjudication, contested. Any comprehensive theory of the adjudicative process must see and account for what is obscured by our habitual thinking about adjudication: before there can be the application of a rule to a "particular," "particulars" themselves must emerge as the interpreted outcome of a process culminating in a particular kind of judgment. That process and judgment constitute the subject of this Note.

The Note explores some of the inadequacies of the "rule-of-law" conception of adjudication in the context of a particular case, and proposes an alternative account of the process of judicial fact construction. ${ }^{13}$ Part $\Pi$ analyzes the opinions of the Supreme Court in County of Allegheny v. ACLU, ${ }^{14}$ looking first to the different interpretive approaches employed within the case and second to the variety of outcomes generated by the application of a single approach, in this case the "endorsement test." 15 Part III attempts to show that the interpretive quality of adjudicative understanding is such that the hard distinction between law and fact should be rethought in light of the unavoidable interpenetration of law and fact. Part IV discusses the act of judgment in and through which a case or controversy's facts become a legally cognizable fact pattern. The Note concludes in Part V by linking the species of judgment involved in fact construction to the "practical wisdom" strain of contemporary jurisprudence. While most closely related to that mode of theorizing, the synoptic judgment employed in judicial fact construction deserves a role not just in one, but in every theory of adjudication aspiring to completeness.

\section{Constitutional AdJudication as METHOD AND as INTERPRETATION: COUNTY OF ALLEGHENY V. ACLU}

This section uses the Allegheny decision to show that the crucial determinants of the cpinions do not come down either to issues of interpretive methodology or disputes about the "raw facts." Rather, competing premethodological constructions of the fact situation ${ }^{16}$ played a central role in the disposition of the case. Competing characterizations of the same raw facts are, in

be reduced to one or the other. The Constitution's meaning emerges in a kind of dialogue in and through which the interpreter engages the text. Because the Constitution has a history of interpretation, and because, in interpreting it, we place ourselves within that history, exclusive reliance on either original intent or contemporary values is, in principle, impossible. See Hoy, A Hermeneutical Critique of the Originalism/Nonoriginalism Distinction, 15 N. KY. L. REV. 479, $491-95$ (1988) [hereinafter Hoy, Hermeneutical Critique].

13. The Note does not purport to challenge the idea of the rule of law per se, nor does it quarrel with the rule-of-law values mentioned above. See supra note 4 . The Note seeks rather to challenge prevailing theoretical prejudices concerning the idea of the rule of law, especially insofar as they impede our understanding of the actual adjudicative process.

14. 109 S. Ct. 3086 (1989).

15. See infra notes $18-22$ and accompanying text.

16. By "premethodological" this Note refers to that stage in the adjudicative process, evidence of which may or may not appear in the justificatory section of the opinion, at which the controversy takes factual "shape." $C f$. K. LlEWELLYN, THE COMMON LAW TRADITION 226-35 (1960) (discussing importance of background setting in adjudication). 
turn, possible, not simply because the Justices have distinct political visions, but because constructions of social fact depend upon tradition - and the tradition of social understanding of religion in America is itself a sustained argument among contending voices. ${ }^{17}$

\section{A. Two Rule-Oriented Approaches to the Establishment Clause: The Crèche Decision}

County of Allegheny v. $A C L U^{18}$ is the latest in a series of decisions by the Supreme Court attempting to determine the constitutionality of religious symbols placed in public spaces. In a Court marked by strong differences, the Allegheny decision is especially noteworthy for the sharpness of its disagreements and the rancor of its tone. The decision includes five different opinions, and there is no single opinion of the Court on the menorah issue.

The case tested the constitutionality of two religious symbols: one, a crèche displayed on the grand staircase of the Allegheny County Courthouse in Pittsburgh; the other, a Chanukah menorah placed just outside the City-County building in the company of a Christmas tree and a sign saluting liberty. The Court of Appeals for the Third Circuit held both the creche and menorah displays unconstitutional; because they failed the test articulated in Lemon $v$. Kurtzman, ${ }^{19}$ they were found impermissible endorsements of religion. By a 5-4 margin, the Supreme Court held the crèche an unconstitutional endorsement of religion; by a 6-3 difference, however, the Court found the menorah a permissible symbol not having the prohibited effect of endorsing religion. ${ }^{20}$

In spite of the decision's five-part cacophony, two basic decision strategies are discernible. The first is well expressed by Justice Blackmun for the Court in Part III-A of the decision:

Whether the key word is "endorsement," "favoritism," or "promotion," the essential principle remains the same. The Establishment Clause, at

17. For a discussion of tradition as being constituted by ongoing dialogue on the subject of the tradition's own meaning, see A. MACINTYRE, AFTER VIRTUE 220-25 (1981). The possibility of conflicting interpretations of a given tradition, like the possibility of difference in the judicial interpretation of social reality, is not an enigma and not something to be wished away.

18. 109 S. Ct. 3086 (1989).

19. 403 U.S. 602 (1971). Lemon articulated the most frequently used measure for determining the constitutionality of a practice challenged on establishment clause grounds:

Under the Lemon analysis, a statute or practice which touches upon religion, if it is to be permissible under the Establishment Clause, must have a secular purpose; it must neither advance nor inhibit religion in its principal or primary effect; and it must not foster an excessive entanglement with religion.

Allegheny, $109 \mathrm{~S}$. Ct. at 3100. The endorsement test employed in Allegheny was Justice O'Connor's adaptation of the second Lemon prong to specific situations.

20. Four Justices voted to reverse the Court of Appeals on both symbols (Kennedy, Rehnquist, Scalia, and White). Three Justices voted to affirm the lower court on both symbols (Brennan, Marshall, and Stevens). Justices Blackmun and O'Connor voted with the majority on both symbols, judging the menorah constitutional and the crèche unconstitutional. 
the very least, prohibits government from appearing to take a position on questions of religious belief or from "making adherence to a religion relevant in any way to a person's standing in the political community."21

The constitutionality of a challenged practice is thus to be determined according to an endorsement test. If the practice conveys a message that a particular religion or religious belief is "favored or preferred," 22 or if a practice promotes one religion at the expense of another or at the expense of no religion, ${ }^{23}$ it will be said to endorse that religion and will therefore be found unconstitutional.

The second method for testing the constitutionality of the symbols is illustrated in Justice Kennedy's opinion. Dissenting on the issue of the crèche's constitutionality, Kennedy rejects the crèche majority's ${ }^{24}$ preference for the application of a doctrinal test and cautions the Court against falling into the trap of mechanically applying a "formalism that does not exist." ${ }^{25} \mathrm{He}$ stresses the possibility of governmental recognition and accommodation ${ }^{26}$ of religion. The Kennedy approach is exemplified in this statement: "In determining whether there exists an establishment, or a tendency toward one, we refer to the other types of church-state contacts that have existed unchallenged throughout our history, or that have been found permissible in our caselaw." ${ }^{27}$ He concluded that because the Court had in the past upheld the constitutionality of some crèche displays, ${ }^{28}$ legislative prayer, ${ }^{29}$ benefits to religious schools, ${ }^{30}$ and tax exemptions for religious organizations, ${ }^{31}$ both the crèche and menorah were constitutionally permissible.

In sum, the crèche component of the Allegheny decision illustrates a difference in decisional outcome based upon a difference in decision strategy. For proponents of a doctrinal test, religious symbols will necessarily fall on either side of a threshold of impermissibility, depending upon whether the symbol can

21. 109 S. Ct. at 3101 (opinion of Blackmun, J.) (quoting Lynch v. Donnelly, 465 U.S. 668, 687 (1984) (O'Connor, J., concurring in judgment)).

22. Wallace v. Jaffree, 472 U.S. 38,70 (1985) (O'Connor, J., concurring in judgment).

23. See Epperson v. Arkansas, 393 U.S. 97 (1968).

24. See supra note 20.

25. $109 \mathrm{~S}$. Ct. at 3135 (Kennedy, J., concurring in judgment in part and dissenting in part).

26. Justice Kennedy uses the term "accommodation" nontechnically to mean, roughly, "provide a space for" or "give room to." In recent establishment clause jurisprudence the term had acquired a more technical, doctrinal sense, referring to governmental action to remove a burden on the free exercise of religion imposed somehow by the government. See Corporation of Presiding Bishops v. Amos, 483 U.S. 327, 347-48 (1987) (O'Connor, J., concurring in judgment).

27. $109 \mathrm{~S}$. Ct. at 3137 (Kennedy, J., concurring in judgment in part and dissenting in part).

28. Lynch v. Donnelly, 465 U.S. 668 (1984) (crèche included in public Christmas display depicting origins of holiday did not violate establishment clause). tional).

29. Marsh v. Chambers, 463 U.S. 783 (1983) (opening legislative session with prayer not unconstitu-

30. Everson v. Board of Educ., 330 U.S. 1 (1947) (state-supported transportation for children to private schools not unconstitutional).

31. Walz v. Tax Comm'n of N.Y., 397 U.S. 664 (1970) (property tax exemption for religious groups not unconstitutional). 
fairly be said to promote, favor, or endorse one or any religion. For the dissenting four, there is reference to doctrine, but the dispositive factor is history, where history incorporates both the substantive outcomes of prior constitutional challenges as well as historically unchallenged practices. For the latter, historical approach, ${ }^{32}$ accepted practices of the past form a kind of constellation. If the currently challenged practice can be fitted into the overall configuration, without distorting its overall shape, it will be constitutional.

The crèche decision thus presents two different decision strategies (the doctrinal and the historical) at work in constitutional decisionmaking and, as one might expect, the two strategies generate conflicting outcomes. As such, the crèche decision illustrates the problematic of interpretation conceived as a problem of interpretive methodology in constitutional adjudication, and suggests that if we could settle on the appropriate decisional strategy, such conflicts might be eliminated.

\section{B. The Menorah Decision and the Breakdown of the Rule-Oriented Approach}

The menorah component of the Allegheny decision, however, threatens this method-centered hope in a fundamental way. For when the crèche majority turns to confront the issue of the menorah, the consensus disintegrates.

If a five-Justice majority agrees about the relevant caselaw, placing the current controversy in a line from Everson through Lemon and Lynch to the present, and if that same majority can agree about the result those cases dictate in the case of crèche, how is it that they disagree on the matter of the menorah? How does a group of Justices demonstrably in agreement on interpretive methodology, ${ }^{33}$ and capable of concerted application of that method to the crèche facts, differ so sharply upon the application of relevant doctrine to the menorah problem?

The answer lies in a fact, very close to the surface of the Allegheny opinion (and latent in so many other opinions): it is not only a matter of constitutional interpretive methodology that divides the Justices, but differences in the interpretation of legal and social facts. To see how this is so, one need only look to opinions of Justices Brennan, Blackmun, and O'Connor on the constitutionality of the menorah.

32. It is important to stress that this is only one of the many ways of using constitutional history.

33. In Allegheny Justice Blackmun combines the Lynch concurrence (of Justice O'Connor) with the four Lynch dissenters to forge a working "doctrinal" majority, whose approach to establishment issues can be used as a guide to further challenges. $109 \mathrm{~S}$. Ct. at 3101-03 ("Thus, despite divergence at the bottom line, the five Justices in concurrence and dissent in Lynch agreed upon the relevant constitutional principles [expressed in the endorsement test]."). 


\section{Justice Blackmun on the Menorah}

Commencing his analysis of the menorah issue, Blackmun writes:

[T] he relevant question for Establishment Clause purposes is whether the combined display of the tree, the sign [placed by the city, saluting liberty], and the menorah has the effect of endorsing both Christian and Jewish faiths, or rather simply recognizes that both Christmas and Chanukah are part of the same winter-holiday season, which has attained a secular status in our society. ${ }^{34}$

He finds no endorsement. Though it has religious origins, the tree, he believes, is a secular symbol. Placed adjacent to the menorah, the forty-five-foot tree "communicates" a secularity to the eighteen-foot menorah because the tree is the "predominant element" 35 in the display. Therefore, it is "much more sensible to interpret the meaning of the menorah in light of the tree, rather than vice versa." ${ }^{36}$ The incorporation of a sign saluting liberty "confirm[s] that in particular contexts the government's association with a religious symbol does not represent the government's sponsorship of religious beliefs. ${ }^{37}$ Interpretation of the menorah's meaning depends not only upon its physical setting; it must also "take into account the perspective of one who is neither Christian nor Jewish .... [T]he constitutionality of its effect must also be judged according to the standard of a 'reasonable observer." ${ }^{\prime 38}$ And to support his opinion, he rules out the possibility that the combined tree-sign-menorah display will be understood to endorse Judaism alone. In support of this assertion, he cites demographic data to the effect that only 45,000 of Pittsburgh's 387,000 residents are Jewish. That Judaism is a minority faith in the region makes a message of endorsement unlikely (although, he cautions, not impossible in other circumstances).

\section{Justice O'Connor on the Menorah}

O'Connor disagrees strongly with what she sees as Blackmun's implied characterization of the Christmas tree as religious. ${ }^{39}$ For her the tree is a predominantly secular symbol. Consequently, the issue is not whether the display endorses both religions (the tree could not endorse Christianity) or none. Rather, it is "whether the City of Pittsburgh's display of the menorah, the

34. Id. at 3113 (opinion of Blackmun, J.).

35. Id.

36. Id. at 3114 .

37. Id. at 3115 (citing Lynch v. Donnelly, 465 U.S. 668,707 (1984)).

38. Id. (citing Witters v. Washington Dept. of Servs. for Blind, 474 U.S. 481,493 (1986) (O'Connor, J., concurring in part and concurring in judgment)).

39. Blackmun's suggestion that the display endorsed either both faiths or neither faith tacitly assumes that the tree is in some sense a symbol of Christianity. 
religious symbol of a religious holiday, next to a Christmas tree and a sign saluting liberty sends a message of government endorsement of Judaism or whether it sends a message of pluralism and freedom to choose one's own beliefs." 40

Although the menorah is a religious symbol of a religious holiday, its accompaniment by a sign erected by the city of Pittsburgh saluting liberty "indicates that the city intended to convey its own distinctive message of pluralism and freedom." ${ }^{\text {"41 }}$ Thus, in interpreting the ultimate message of the display:

A reasonable observer would, in my view, appreciate that the combined display is an effort to acknowledge the cultural diversity of our country and to convey tolerance of different choices in matters of religious belief or nonbelief by recognizing that the winter holiday season is celebrated in diverse ways by our citizens. In short, in the holiday context, this combined display in its particular physical setting conveys neither an endorsement of Judaism or Christianity nor disapproval of alternative beliefs, and thus does not have the impermissible effect of "mak[ing] religion relevant, in reality or public perception, to status in the political community." 42

\section{Justice Brennan's Dissent on the Menorah}

Brennan, joined by Marshall and Stevens, judges the menorah unconstitutional. He accuses Blackmun and O'Connor of forgetting their own general interpretive premise: "that context is all-important in determining the message conveyed by particular objects." ${ }^{43}$ Accordingly, the meaning of the Christmas tree, in light of its adjacency to the menorah, is primarily religious. As for the menorah itself, "it is most likely that the religious aspects of the menorah would be front and center in this display." 44

Explicitly addressing the otherwise undiscussed problem of factual interpretation, Brennan writes that he would not presume to say which interpretation of the tree's significance is the correct one (religious, because adjacent to the menorah; secular, because generally regarded as such). Without giving any content to his own "reasonable person" standard, he "shudder[s] to think that the only 'reasonable observer' is one who shares the particular views on perspective, spacing, and accent expressed in Justice Blackmun's opinion $\ldots .{ }^{\prime 45} \mathrm{He}$ then goes on to state boldly that "the city's erection alongside the

40. $109 \mathrm{~S}$. Ct. at 3122 (O'Connor, J., concurring in part and concurring in judgment). Justice O'Connor also disputes Justice Blackmun's emphasis on the secular quality of the Chanukah holiday. Id.

41. Id. at 3123 .

42. Id. at 3123-24 (quoting Lynch v. Donnelly, 465 U.S. 668, 692 (1984)) (emphasis added).

43. 109 S. Ct. at 3126 (Brennan, J., dissenting).

44. Id. at 3127 .

45. Id. 
Christmas tree of the symbol of a relatively minor Jewish holiday ... has the effect of promoting a Christianized version of Judaism." "46 The religious values implicit in the structure of the religions' respective calendars contribute to the meaning of the display and thus to the meaning of the menorah.

\section{The Lesson of Allegheny for Interpretive Adjudication}

In Allegheny constitutionality is a matter of endorsement (or lack thereof). Endorsement is a matter of message. Message is a matter of context. Thus, answering the endorsement inquiry calls for determining the meaning of the symbol in the appropriate context. Context is the traditional remedy for indeterminacy of meaning. In the Allegheny opinion, however, at least eight different notions of context are employed to determine meaning. ${ }^{47}$ Even where there is agreement as to the most relevant contextual factor, the message is understood differently. ${ }^{48}$ Since "the question 'whether a government activity communicates an endorsement of religion' is 'in large part a legal question to be answered on the basis of judicial interpretation of social facts," $" 49$ at least this particular interpretation of the Constitution necessarily turns upon the "judicial interpretation of social facts." Even when Justices agree about the appropriate doctrinal mechanism for spelling out the demands of the establishment clause, its present meaning necessarily turns on more than original text or contemporary doctrine. Its present meaning (and so, the outcome of the case) depends ultimately on which of the available notions of context provides the solution to the menorah's true significance. Which is to say, it is the legally relevant conception of context that is crucial. ${ }^{50}$ Thus, to answer the endorsement inqui-

46. Id. at 3128-29.

47. These are 1) context as determined by the "physical setting," $109 \mathrm{~S}$. Ct. at 3123 (O'Connor, J., concurring in part) which could be further divided into setting-as-backdrop (the building/property) and setting as the adjacent symbols; 2) "[t]he absence of a more secular alternative symbol is itself part of the context," 109 S. Ct. at 3114 (opinion of Blackmun, J.); 3) the total demographic makeup of the Pittsburgh area, 109 S. Ct. at 3113 n.64 (opinion of Blackmun, J.); 4) the overall "holiday context," 109 S.Ct. at 3123 (O'Connor, J., concurring in part and concurring in judgment); 5) context as the way adherents in the community understand history, $109 \mathrm{~S}$. Ct. at 3127 (Brennan, J., concurring in part and dissenting in part); 6) undisputed factual history, e.g., the historical facts of Christ's life, $109 \mathrm{~S}$. Ct. at 3128 (Brennan, J., concurring in part and dissenting in part); 7) the relative importance of the symbolized holiday in the calendar of that faith, 109 S. Ct. at 3128-29 (Brennan, J., concurring in part and dissenting in part); 8) and the history of related unchallenged practices combined with all those related practices that survived constitutional challenge, 109 S. Ct. at 3137-38 (Kennedy, J., concurring in judgment in part and dissenting in part).

48. Compare Blackmun's claim that the tree communicates a message of secularity to the display, supra note 35 and accompanying text, with Brennan's claim that the menorah confers a religious nature upon the very same display, supra note 44 and accompanying text.

49. $109 \mathrm{~S}$. Ct. at 3112 n.60 (opinion of Blackmun, J.) (quoting Lynch v. Donnelly, 465 U.S. 668, 69394 (1984) (O'Connor, J., concurring)).

50. So, for instance, the menorah inquiry incorporates answers to the questions "Who acted?," "What message was sent?," "Who was the receiver of the message?," and so on. The answers to these questions can be distinguished ex post, that is, after the configuration of the total situation is determined, but the responses are interdefining. One cannot determine the answer to the "what message" question without determining who the relevant receiver is, and, vice versa. See infra notes 57-59 and accompanying text. 
ry, the Justices must interpret the social world in light of those factors in it which are legally salient. But if this is true, the actual process of decision could never assume the form of an application of a legal rule to a set of facts, because the relevant facts (the context) are, by reason of their relevance, already legal facts. It is this fact of adjudication that makes the core of the menorah decision a judgment and not the application of a rule to a situation.

In adjudication, the judge sees as a judge, and so the configurative integrity of fact situations is a joint synthesis of fact, law, and judicial understanding. Though facts can be characterized extralegally (imagine an engineer's or physicist's account of the raising of the Christmas tree), the judge does not encounter them prelegally, but rather only upon the terrain of the legal landscape. That is why, strictly speaking, it does not make sense to speak of the application of law to fact without reference to the synthetic act of judgment in and through which the law is made to shape the facts and the facts to fall under the law.

Understanding a text such as the Constitution can never be either a matter of merely consulting the semantic context of the Constitution's origin or of the world of the contemporary interpreter. Interpreting the Constitution involves a joining or fusing of the original context of the text and the contextual world of the interpreter. Neither context is dispensable, and textual meaning can never be reduced to one or the other. The meaning of the Constitution emerges in a kind of dialogue in and through which the interpreter engages the text in relation to the facts of the present controversy.

Thus, where the standard model posits a contemporary, but historically unconditioned, interpreting subject who then chooses among contexts in which to situate the constitutional text, the judge is actually a historically conditioned interpreter capable of engaging a text such as the Constitution because the text itself and the history of its effects are constitutive elements of the very tradition in and through which the judge comes to understand. The judge is also capable of adjudicating fact situations because constitutional adjudication itself is a discipline, a practice cultivated through progressive familiarization with contested situations.

As to texts, in understanding them we apprehend them as contextualized in historically conditioned ways. We do not first consult the text and then elect to place it in a context; rather we encounter it in a dialogue in which its original context, the history of its interpretations, and the "raw facts" of the contested situation merge. And the centerpiece of this confluence is the actual language of the text itself. The judge occupies a particular historical position in regard to the text; ${ }^{51}$ because she stands within, rather than above the stream

51. Cf. Linge, supra note 7 , at $\mathrm{xv}$ ("The role of the past cannot be restricted merely to supplying the texts or events that make up the 'objects' of interpretation. As prejudice and tradition, the past also defines the ground the interpreter occupies when he understands."). 
of history, she is not free to pick and choose among contexts or methods that privilege an isolated past or an immediate present.

The stage at which the facts emerge in the form of a fact pattern precedes the application of any interpreting methodology. The application of a methodology, however useful, is not interpretive understanding. As with texts, to understand is already to have begun to interpret the facts. There do not exist three distinct acts-interpreting the text simpliciter, interpreting the facts, and then applying the one to the other. Another way to express this is to say that situations are also always interpreted. The facts of a legal controversy do not stand naked, ready to be subsumed under a distinct binding instrument called the law. Rather, "[C]ircumstances must be understood within the law . . . ."52 In applying the constitutional clause/doctrinal provision to the facts of a given case there is a mutuality, an integrated reciprocity. The facts assume salience and shape in light of their relevance to the interpreted text; the text realizes itself, becomes meaningful through its application in the particular case. ${ }^{53}$ The text cannot be fully understood without reference to facts: there are not two distinct stages of interpretation, but ultimately one synthesizing judgment.

The exercise of such judgment is an integrative interplay of law and fact, a practice grounded in the larger web of practices we call judging. That practice is fully intelligible only within the very tradition the judge reinterprets in the process of judging. ${ }^{54}$ Traditions carry forth legal, social, and political practices of a generality sufficient to make them shareable, but which must constantly address themselves to the concrete particulars of new situations. For the interpreter situated within a tradition, understanding both law and fact is a practice in which tacit processes of judgment operate within the present situation and out of the fund of experience provided by the tradition. The present, in both the context(s) of textual interpretation, and in the context of the factual situation, owes its intelligibility to the shaping action of tradition. Because present contexts are shaped by the past, they always arrive already interpreted. That

52. J. WEINSHEMER, supra note 11, at 191; see also Linge, supra note 7, at xlvii ("All deliberate interpretation takes place on the basis of [human being's] historicity, that is on the basis of a prereflective understanding of being from within a concrete situation that has intrinsic relation to the interpreter's past and future.").

53. See J. WEINSHEIMER, supra note 11 , at 191.

Whenever judgment is necessary ... . what a rule means (its interpretation) will be indivisible from and in part determined by, the instances to which it is applied. . . . [N])t only is the general applied to the particular in the act of judgment, but also the particular is applied to the general. They supplement and complement one another reciprocally. Such judgment ... requires a weighing of both. . . . This is phronesis, the virtue of reflective deliberation that determines right application.

54. Emphasis on the traditions of shared practice unites otherwise quite different contemporary theorists (and antitheorists) of constitutional interpretation sometimes called "conventionalists." See, e.g., Kronman, Alexander Bickel's Philosophy of Prudence, 94 YALE L.J. 1567 (1985) (conservative conventionalism); Fiss, Objectivity and Interpretation, 34 STAN. L. REV. 739 (1982) (liberal conventionalism); Fish, Dennis Martinez and the Uses of Theory, 96 YALE L.J. 1773 (1987) (deconstructive conventionalism); see also infra text accompanying notes 73-77. 
is why present controversies cannot consist of raw facts which order themselves into fact patterns.

\section{SYNOPTIC JUDGMENT IN ADJUDICATION}

\section{A. How "Facts" Become "The Facts"}

Interpretation of fact is typically thought to occur at the trial court level. It is a problem then for the primary factfinder (judge or jury); the function of appellate courts is generally confined to interpreting the law. ${ }^{55}$ Yet, in Alleghe$n y$, the crucial element in the disposition of the crèche issue is the interpretation of the factual record-a record established below and not seriously questioned at the Supreme Court. ${ }^{56}$

Determining the constitutional significance of the menorah is a matter of judging the meaning it conveys in context. Such judgments are synthetic. In making the determination, each judge asks (if only implicitly), "What happened?" Any answer to the factual question, that is any judge-made configuration of the facts, must, in the context of the judicial inquiry into the situation (e.g. in Allegheny "the controlling endorsement inquiry"), respond to the "what happened" query in a way that selects from the multiplicity of available characterizations of the facts the interpretation that organizes the relevant facts in light of the specific inquiry. ${ }^{57}$ In one synoptic act of synthesis the judge "sees" the situational totality of the case, and understands it as a unified whole. ${ }^{58}$ Reference to the law does not typically appear in an opinion's account of the facts, but it is by reference to the law that the facts hang together for this case.

Thus, before there is any final rational accounting, the judge must arrive at some conclusion about the significance of the facts taken as a whole situation. Interpreting the facts means arriving at a sense of their significance not as a concatenation of discrete events, but as an integrated whole. The judgment in and through which the events are brought together is a synthetic act in which the facts are arrayed configuratively rather than episodically. ${ }^{59}$

55. There are instances in which higher courts find facts and review lower court fact determinations. Generally the reality of factual interpretation is recognized as an issue for the lower courts. See, e.g., J. FRANK, COURTS ON TRIAL 74 (1950). For a discussion of higher court review of lower court fact determinations, see Monaghan, Constitutional Fact Review, 85 CoLUM. L. REV. 229 (1985).

56. But see $109 \mathrm{~S}$. Ct. at 3096-97 n.29 (Blackmun, J., chiding court of appeals for its reading of record on menorah issue).

57. The philosopher of history R.G. Collingwood stressed this same phenomenon of understanding in developing his "logic of question and answer." See L. MINK, MIND, HISTORY, AND DIALECTIC 121-38 (1969).

58. The judicial elaboration of the explanatory rationale is thus an unpacking of a synthesis cognitively and temporally prior to the justificatory reasoning that appears in the opinion. See supra note 50 and accompanying text.

59. For discussion of the difference between events grasped episodically and events grasped configuratively, see P. RICOEUR, TMME AND NARRATIVE 64-67, 155-61 (1984). 
As the menorah case illustrates, and as Gadamer's phenomenological hermeneutics suggests, even appellate-level judges are in the business of interpreting facts-and they are doing it as they interpret the law. The notion that facts are interpreted, and not self-presenting "bare" facts, is not a new one. ${ }^{60}$ Jerome Frank stressed long ago that "[t] he trial court's facts are not 'data', not something that is 'given'; they are not waiting somewhere, ready made for the court to discover, to 'find." "61 This is perhaps most obvious in the case of a criminal trial in which judges and juries must interpret the accounts of witnesses' remembering (and, so, interpreting for the present) their past perceptions (themselves interpretations, since they are perspectives ori the events witnessed, not the events themselves).

Frank, however, was not much concerned with higher courts' interpretations of the facts. "[O]rdinarily, in an upper court, no factfinding problem exists, because the facts are beyond dispute, having been 'found' by the trial court." 62 Frank does not press his antipositivism far enough. In light of the menorah case, it seems more faithful to the reality of the interpretive situation to stress that the constitutional provision (here, the establishment clause) as mediated through the doctrinal lens (here, the endorsement test) projects itself over the facts as their interpretive horizon. They become not merely the facts, but the facts-for-the-inquiry. They "constitute" a unified set because of their interrelatedness; and their interrelatedness, far from being merely given, is an outgrowth of their (the facts, that is) jointly constituting the answer to the question: What (of constitutional relevance) happened here?

The facts of a given case are therefore potentially meaningful because as an ensemble they can assume a significance they do not possess as a mere list of facts. They are related, bound together by the law around which they cluster. A positivist catalogue of facts could never constitute a fact pattern. Facts in their interrelatedness, not their discreteness, are intelligible as a comprehensible whole. "Bare facts" can be added together, but could never "add up" to anything.

But if the facts "add up" to an intelligible, comprehensible pattern, what can be said, even in general, of that pattern's structure?

\section{B. Kelman and the Interpretation of Facts}

Mark Kelman contends that "legal argument has two phases, interpretive construction and rational rhetoricism." ${ }^{63}$ For Kelman, interpretive construction

60. Nor, obviously, is it unique to the thought of Gadamer. A signal advantage of the Gadamerian approach, however, is its emphasis on the way the inquiry of understanding itself shapes, and is shaped by, the facts in the process of understanding.

61. J. FRANK, supra note 55, at 23.

62. Id. at 328. But see id. at 47 ("Even in upper courts, where all the testimony is in writing, the ablest judges often differ with one another about the facts of a case.").

63. Kelman, supra note 2, at 591. 
involves "processes by which concrete situations are reduced to substantive legal controversies," 64 both in the shaping of legally cognizable factual situations and in the framing of the applicable legal rules. "Rational rhetoricism" is the stuff of legal analysis; "interpretive constructs" set the table for the rationalization. Kelman's concern is with the operation of these interpretive constructs in the criminal law, and his purpose is deconstructive. However, the kind of interpretive construction Kelman adumbrates actually occurs outside the criminal law as well, and his insights can be put to constructive use in understanding the adjudicative process in general.

Kelman divides interpretive constructs into two types-conscious and unconscious. Four "unconscious interpretive constructs" are at work in the characterization of any fact pattern. First, the events of a given incident can be framed narrowly or broadly. Second, they can be given a disjoined or unified account. Third, broader or narrower views of intent may be employed to give meaning to the action. Fourth, the involved party may himself be viewed broadly or narrowly. ${ }^{65}$

Leaving aside the specific implications of Kelman's theory for the criminal law, he has clearly outlined certain general modalities by which we characterize factual situations. Though he nowhere identifies them as such, the constructs he describes are fundamental devices of narrative form itself. Broad and narrow time frames correspond to the idea of setting. Disjoined and unified accounts of events correspond to the idea of plot. Broad and narrow views of intent are variations of motive. Broad and narrow views of the parties correspond to the idea of character.

That each of these constructs is a device of narrative form is important because jointly they constitute a vocabulary of components for understanding that is neither a mechanical logic of forms nor a mere assemblage of unrelated units. In his rush to assert the irrationality of "interpretive construction," however, Kelman offers no theoretical account of how the constructs interact. Presumably, he has isolated each modality of interpretive construction from a situational synthesis; in practice the substantive particulars of any concretely constructed situation will be interdependent. (That is what is implied by calling the interpretively constructed synthesis $a$ situation.) Though analytically distinguishable, the interpretive constructs are practically interdefining. Notions of intent implicate ideas of character; ideas of character implicate more or less unified accounts of action; and so on. Thus, situational construction is not irrational at all. Neither is it "rational" in the limited sense of being governed by a rule. Rather, interpretive construction has the intelligible unity of a dramatic, rather than logical, whole.

64. Id.

65. See id. at 593-96, 600-42. 
Kelman's view suggests that judges construe factual situations as something like the emplotted wholes we recognize as completed narratives. When something becomes a case at all, it must, in order to be meaningful, present itself as a coherent situation, one in which "an ensemble of interrelationships of many different kinds" is "bodied forth as a single whole." 66 Since a crucial part of the judicial task is to bring the facts into legal focus, the judge cannot treat the facts as historians treat a chronicle, that is, as discrete units, chronologically arranged. Rather, the judge becomes like the historian proper. He sees the facts of the case in a posture of retrospective synthesis-one in which "relevance to the law" is the crucial factor in their being coherent at all.

\section{Interpretive Construction as Synoptic Judgment}

Thus, the statement of facts is not simply a description of an inert body of evidence to which the law is just applied. The law already informs the evidence as the gravitational force pulling just these facts into the field. ${ }^{67}$ The judgment in and through which the facts are composed into a "fact pattern" susceptible of judicial treatment and legal resolution is a distinctive act of the judge. It is crucial to the rendering of legal decisions. It is a matter of judgment and feature of judging, an overlooked dimension of practical reasoning. ${ }^{68}$

Almost forty years ago, in Courts on Trial, Jerome Frank suggested that lawyerly treatment of facts could be compared with profit to that of the historian. ${ }^{69}$ In the light of Kelman's articulation of what I have suggested are the "narrative" modalities of interpretive construction, consider this observation by the philosopher of history Louis Mink, addressing the problem of understanding in history:

[T]he historian deals with complex events in terms of the interrelationship of their constituent events .... . Even supposing that all of the facts of the case are established, there is still the problem of comprehending them in an act of judgment which manages to hold them together rather than reviewing them seriatim. . . . [Historical understanding] is neither a technique of proof nor an organon of discovery but a type of reflective judgment. $^{70}$

This species of judgment, which Mink calls "synoptic judgment" is by no means the special activity of historians. It is exercised by the judge who understandingly integrates submissions of fact into a coherent picture. This act

66. L. MINK, Narrative Form as a Cognitive Instrument, in HISTORICAL UNDERSTANDING 198 (B. Fay,

E. Golob \& R. Vann eds. 1987).

67. See J. WEINSHEIME, supra note 11 , at 191.

68. See infra note 71 and accompanying text.

69. See J. FRANK, supra note 55, at 37-40.

70. L. MNK, The Autonomy of Historical Understanding, in HISTORICAL UNDERSTANDING, supra note 66 , at 77 . 
of comprehending judgment is not described in the opinion; it does not appear anywhere in the decisional text. By its very nature such a judgment could never be described in a form faithful to its actual happening. Nonetheless, it is an act of the synthetic legal imagination, disciplined (but not rule-governed) by a fund of prior legal practice operating through it. It is a component of what some legal theorists have called "practical reasoning." 11 is not a discursive phenomenon, not the concatenating process of fact gathering. Rather, it is judgment as a type of seeing, seeing the whole of a factual field as constituting a unity integrated in the light of the applicable law.

That the type of judgment identified above appears nowhere in the legal opinion should not be surprising. It is an unchangeable fact of language that linguistic expression must be given linear extendedness. A synthetic judgment in which a multiplicity is brought into focus as unified whole cannot be described in a single word. What can be understood as a unity, can only be explicated at length. Furthermore, "the opinion has no function of describing the process of deciding."72

Synoptic judgment is a stage in the adjudicative process which evades description; it cannot be part of the opinion's process of justification ${ }^{73}$ because it is temporally prior to any justification as the cognitive ground out of which any legal rationale (presuming a legally/factually coherent situation) must emerge.

Unlike the judge, the historian, as historian, aims at understanding for its own sake. Constructing a whole historical narrative and grasping it as a whole in synoptic judgment is the telos of historical activity. It is oriented toward the past as its subject. It therefore differs from the synoptic judgment of the judge. The judge grasps the relevant facts and organizes them in a form that answers the question "What of legal relevance happened?" For the judge, this activity is no end, but a stage in a practical process with a double orientation-to the past for the stuff of the judgment and to the future for its interpretive outcome and binding effect. Judicial synoptic judgment while reflective (like the historian's judgment), is not an end in itself, but a stage in a practice: the "reflective deliberation that determines right application." 74

\section{CONCLUSION}

Synoptic judgment of the sort sketched above might be added to that "grab bag of methods" Richard Posner has identified as belonging to the idea of

71. For discussions of the role of practical wisdom in adjudication see Farber \& Frickey, Practical Reasoning and the First Amendment, 34 UCLA L. REV. 1615 (1987); Wellman, Practical Reasoning and Judicial Justification: Toward an Adequate Theory, 57 U. COLO. L. REV. 45 (1985).

72. K. LlewellyN, supra note 16, at 131 (emphasis added).

73. Or as Kelman calls it, the process of "rational rhetoricism," supra note 2, at 592.

74. See J. WENSHEMER, supra note 11 , at 191. 
practical reason in recent jurisprudence. ${ }^{75}$ Synoptic judgment is not, it must be underscored, a method, but a way of judging that yields understanding. It is cultivated by persons, lawyers and judges, trained in the recognition of legally cognizable fact patterns.

The idea that judges employ synoptic judgment in the construction of judicially cognizable fact patterns does not mean that "rule-of-law" values of the sort adumbrated above should be abandoned. Nor does it necessarily call for the relinquishing of every methodological, rule-based method of dealing with legal issues. Proponents of rule-based adjudication who have heretofore bypassed the configurative step in judging, the step in which (through synoptic judgment) the situation takes shape, must now complicate their own accounts of judging. Application of rules in adjudication may still have a place. The point here is that the application of any method is logically posterior to and cognitively dependent upon synoptic judgment. Not "no method," but rather "not by method alone" is the teaching of the concept of synoptic judgment.

The argument offered above can be understood as a contribution to what Posner calls the antireductionist strain of jurisprudential conventionalism. ${ }^{76}$ The existence of synoptic judgment stands as a counterexample to Posner's claim that "the skills component of legal training can easily be decomposed into skills that are not peculiar to law: close reading, careful writing, elementary logic." "77 Because Posner's overriding vision of adjudication is one in which judges apply rules-a vision of law as an "analytic system"78 - he finds the foregoing list of skills exhaustive. But as a synthetic (as opposed to analytic) activity, the mode of judgment sketched above necessarily evades any analysisbased conception of jurisprudence. That, however, does not mean that synoptic judgment does not exist; rather it suggests that a prescriptively narrow conception of "legal skill" cannot encompass it.

Latent in Posner's suggestion that "elementary logic" (along with close reading and writing) is the central skill acquired in legal training (and not so latent in his conception of a common law in the service of economic efficiency) is a conception of adjudication as a thoroughly "rationalized" process. In connection with his work on Max Weber, Professor Kronman has discussed the insistent post-Enlightenment demand for rationality in understanding. By rationality, the "claims of reason," Kronman means two things: "first, a demand

75. Posner, The Jurisprudence of Skepticism, 86 MICH. L. REV. 827, 837 (1988). In his discussion of the "methods of practical reason," Posner stuffs into that grab bag authority, reasoning by analogy, interpretation, means-ends rationality, tacit knowledge, and the-test-of-time. See id. at 841-58. I say, "might be added" because practical-wisdom jurisprudence is the place on the current theoretical spectrum where it is a most likely fit. Actually, the account of judgment involved in fact construction, if correct, ought to form a part of any complete theory of interpretation.

76. See Posner, Conventionalism, supra note 3, at 338-45.

77. Id. at 341 .

78. Id. at 347 ("One problem with prudentialism is that it is a mood rather than an analytic system."). 
for intellectual transparency and second, for calculability."79 The tendency to divide institutions and activities into the rational and the irrational is, for Kronman, an unfortunate, but perhaps inevitable, compulsion of the modern Zeitgeist. Practical wisdom, as a recognized reality and a working ideal, stands in danger of being swept away in modernity's hyperrationalistic (and, the other side of the same coin, antirationalistic) current.

This Note has attempted to show that there is something in constitutional adjudication that evades the demand for transparency and calculability. The County of Allegheny v. ACLU illustrates that even in the application of a doctrinal test, there persists an interpretive dimension that eludes adjudicative formalization. As for transparency, the Note has tried to move constitutional adjudication in that direction by elucidating a mode of judgment employed in the comprehension of legally cognizable fact patterns. And as for calculability, this Note has suggested that synthetic judgment can be unpacked, and in a limited way described - but it cannot be reduced to a rule. For the proponent of practical wisdom, this irreducibility is a part of the uniqueness of judgment.

This sketch of synoptic judgment is not likely to satisfy the adjudicative rationalist. Because judges do not say that they are employing synoptic judgment and because no account of it appears in the judicial opinion, the adjudicative rationalist is likely to regard it as at best irrelevant, at worst nonexistent. Synoptic judgment's resistance to analytical transparency is part and parcel of the fact that it is a human ability, a capacity of understanding that eludes full articulation. And so, for the descriptive theorist of adjudication, fact construction through synoptic judgment poses a challenge to be accounted for. Finally, to judges and practitioners, as well as theorists, it is a reminder that, as Karl Llewellyn wrote, "[t]he only guarantee of judicial wisdom will remain the judge." 80

79. Kronman, Living in the Law, 54 U. CHI. L. REV. 335, 874 (1987); see also A. KRONMAN, MAX WEBER 72-95 (1983) (discussing various senses of "rationality" at work in the thought of Weber).

80. Llewellyn, The Constitution as an Institution, 34 CoLUM. L. REv. 1, 34 (1934). 